\title{
Delving into the 'Stressful' Work of Scientific Translators in South América
}

\section{Viviana SOLER*}

Who are those who form part of the scarce breed called scientific translators? In former times bilingual scientists used to translate texts from within their field, and this was beneficial to their own research. However, as science has grown in size and in power on a colossal scale since the twentieth century, the need for scientific translators has become imperative. Scientific translation is a type of translation that seems to be in increasing demand compared to other types of translation in the world. Parallel to the growth in the demand of scientific translations, there has been a considerable increase in the need for scientific translators particularly in South América. The purpose of this work is to refresh a set of conclusions derived from an itinerant lecture, the first of which was held in 2004 and was purposedly reiterated to disseminate and make known the characteristics of the nature and context of the work of the scientific translator in Spanish-speaking communities, particularly in South América and mainly in Argentina. Although both linguistic and extralinguistic variables must be interwoven to be successfully operative in the work of the scientific translator in such a vast territory, for reasons of space economy, the focus of attention in this work centers on the linguistic assistance that must be provided to the scientific translator in South América. In particular, concepts on genre and register and issues proposed by Systemic Functional Linguistics (SFL) will be considered as essential tools for the work of the scientific translator.

Keywords: scientific translator; Spanish; English; genre; register; Systemic Functional Linguistics

\section{Introduction}

Science is a field in which we cannot do without translation, particularly in a world where English has been installed as the language of science. Scientific translation is thus at the service of all knowledge areas to ensure their dissemination and understanding by everyone. Still, not all translators have translation-specific qualifications and/or skill-specific experience to take on a scientific translation. Within this context, two main variables, namely linguistic and extralinguistic - among others - must therefore be interwoven to facilitate global knowledge circulation via scientific translation.

\footnotetext{
* Senior research assistant at Instituto de Investigaciones Bioquímicas de Bahía Blanca (INIBIBB), Consejo Nacional de Investigaciones Científicas y Técnicas (CONICET) / Universidad Nacional del Sur (UNS). E-mail: insoler@inibibb-conicet.gob.ar; ORCID ID: https://orcid.org/0000-0002-9089-1788. (Received 23 June 2021; accepted 29 November 2021)
} 
The linguistic variables involve years of study, training, and practice, whereas the extralinguistic variables require an adjustment to the sociocultural habitat where the scientific translator works. While the trained translator is aware of the needs and demands of scientific translation and therefore works hard to cope with them, the sociocultural habitat where scientific translators are required may not be necessarily so. These variables trigger contrasting forces which lead to unfair and demotivating frustration to scientific translators, such as the fact that it is always in the majority of the cases that the names of the intervening translators in highly advanced scientific papers are forgotten.

\subsection{Itinerant Lecture}

This work aims at summarizing a set of conclusions derived from an itinerant lecture, the first of which was given several years ago, in 2004, on occasion of the 10th National Congress of Teachers and Students of English held in Bahía Blanca city, Buenos Aires province, Argentina, on July 9-10 (Soler 2004). This first presentation was followed by a series of other presentations of this itinerant lecture in the following order: i) 3rd Conference on Multilingualism and 8th Conference on Methodological Exchange in Language Teaching, organized by the Escuela Normal Superior of the Universidad Nacional del Sur (UNS), held in Bahía Blanca, Buenos Aires province, Argentina, in June 2006 (Soler 2006a), ii) 5th Professional Updating Meeting on Translation and Interpretation held at UNS in October 2006 (Soler 2006b), and iii) 5th Conference of the Escuela Superior de Idiomas, in General Roca, Neuquén province, Argentina (Soler 2009a), in which case this itinerant lecture was read in absentia .

In line with the term 'itinerant,' this lecture was purposedly reiterated in an attempt to disseminate and make known the characteristics of the nature and context of work of the scientific translator in Spanish-speaking communities, particularly in South América and mainly in Argentina. The reason why the data herein presented is focused partly on Argentina lies, firstly, in that it is my home country where I am well familiarized with the Argentine scientific system, and secondly, in that it is important to agree that South América is a large non-English-speaking community, and each of the countries within this vast territory has its own sociocultural habitat with characteristics that may differ from one country to another, thus affecting differently the work context of the scientific translator. The rationale of this 
itinerant lecture was to collect the feedback and input from its audience after each presentation and to include it in the next lecture.

After fourteen years from the last stage of the above-described itinerant lecture, it is a good idea to retake the original conclusions and share them with a larger audience by means of this work. It is well known that the list of problems with which the scientific translator is confronted in South América is not only long but also heterogeneous as a result of the nature and subject matter of the texts that a scientific translator is expected to translate, on the one hand, and as a result of the varied sociocultural environments where the scientific translator has to carry out his or her task, on the other. The list includes mainly i) the high demand of work in contrast to the low number of highly specialized scientific translators, particularly in certain Spanish-speaking regions of South América, such as Argentina and Chile (Diéguez Morales, Lazo Rodríguez, and Quezada Gaponov 2014), ii) the rhythm of work to which the scientific translator is exposed, and iii) the language of science, which, according to the general consensus, is English.

\section{Obstacles to the Work of the Scientific Translator}

\subsection{Monopoly of the English Language in Science}

The domain of English as the world's lingua franca of science produces a linguistic monopoly which in turn generates two opposing forces: a positive and a negative one. The former allows the translator, after years of hard training under the supervision of a tutor with expertise in scientific translation, to properly master the conventions and codes of such linguistic monopoly. In this sense, this 'force' is positive, as it has a stimulatory impact on the Spanish-speaking scientific translator of English.

In contrast, the other force is negative or, even worse, detrimental to Spanish. This is because this linguistic monopoly stimulates the prevalence of standard formulas and designations in English but leaves no room for their equivalents in Spanish. This is what happens in translations from English into Spanish with terms, such as 'patch-clamp,' 'pellet,' 'turnover,' just to cite a few. This linguistic phenomenon also favors the invasion of conventions from standard English into Spanish, leading in turn to errors affecting different language areas, such as spelling, lexicon, syntax, among others. On the syntactic level, for example, it is common to see in Spanish an overuse of zero article at the beginning of the 
sentence and of passive voice. On the orthographic level, English spelling rules often interfere with those of Spanish, and it is therefore very common to read, for example, 'proteina' instead of 'proteina' in scientific translations from English into Spanish. This brief outline clearly shows that this linguistic monopoly in science strengthens English but weakens Spanish as long as the Spanish-speaking community in South América does not work towards protecting Spanish from the oncoming English avalanche.

The scientific translator has therefore a potential opportunity in defense of Spanish and must work together with the scientist-whose papers he/she has to translate-in order to start implementing a tactic to generate a standard scientific language that facilitates the communication of knowledge in English but takes care of Spanish at the same time. The difficulty in implementing such a tactic lies in that whereas the scientific translator is indeed aware of the need to do this, the scientist may not be so. Another obstacle for the implementation of this tactic is the pace of science work because science runs at such a speed to have papers published that the chances for implementing this tactic with the scientist's cooperation are almost zero.

Another negative effect of this linguistic monopoly falls on those scientists who, because of their low competence in the English language, must resort to translations into Spanish of scientific papers that are written in English. In this case, only very good translations (i.e., those excelling in grammatical, terminological, semantic, and pragmatic accuracy) will be useful for them; otherwise, the effect will be frustrating for the scientist who paid for a translation that does not fulfill its purpose. Among scientists, whatever the case is in terms of their competence in the English language, the prevailing tendency is a preference for reading and writing science in English - even with difficulties in the case of those having a poor competence in English. Such preference increases the difficulties with which the scientific translator is confronted in Spanish-speaking communities because in Spanishspeaking universities translators are taught to translate scientific texts from English into their mother tongue, in agreement with the general consensus that students of translation should be trained to translate into their mother tongue (Macshane 1976; Orellana 1986). However, the real scenario in South América makes the work of the scientific translator be, in a high percentage, processed the other way around (i.e., from Spanish into English). This phenomenon, which statistically appears to be increasing at present, obliges the scientific translator to work following the conventions of English instead of those of Spanish for which 
he/she was trained. The mental process he/she is expected to develop is consequently more complex because he/she is expected to translate i) into a language that is not his/her own, ii) for a linguistic community that is not his/her own community, and iii) for scientific journalsmost of which have a high impact factor index - that handle codes and conventions that are not his/her own.

\subsection{Time in Science Work}

So far, the summary detailed above shows that the work context of the scientific translator is not only complex but also demanding and is permanently threatened and persecuted by the pace of science work. Science has to run ahead with time in an attempt to meet the needs of the world. Once a finding is confirmed, it should be communicated firstly to the scientific community and then to the general audience. The scientific translator is a crucial link in this process, and everything depends on him/her to ensure that the new findings and their applications effectively reach everybody in an incredibly short time. An everyday situation in which a scientist and a scientific translator should interact could be depicted in the following simple terms: while the scientist may have had a long time, perhaps years, to reach a finding, the translator has no other chance but to translate the entire textual content of that finding 'for yesterday.' In view of the above, one can envisage the numerous daily challenges that make the scientific translator a victim of so many pressures: thematic scientific heterogeneity, dizzying pace of work, mental flexibility, high work demand, pressure imposed by the authors for translations to be delivered in record short times, and the list may go on and on.

\subsection{Sociocultural Habitat Where the Scientific Translator Works}

An interesting issue worthy of consideration in relation to the sociocultural habitat where the scientific translator works in South América can be formulated in terms of the following question: Are scientific translations from English into Spanish required more than scientific translations from Spanish into English? This question was made by a colleague, Patricia Oostdyk, attending the above-mentioned 5th Professional Updating Meeting on Translation and Interpretation held at UNS in October 2006. Oostdyk's comment was that the demand of scientific translations from Spanish into English seems to be higher than from 
English into Spanish in Argentina, a phenomenon which again demonstrates that this does not respond to the general consensus of training translators to translate into their mother tongue. In parallel, she also claimed that this phenomenon cannot be generalized to all Spanishspeaking communities in South América, as the need for scientific translations into either English or Spanish, particularly in Argentina, depends on the characteristics of each area (Patricia Oostdyk, pers. comm.). For example, in Buenos Aires city, the demand of scientific translations into English and Spanish appears to be equally high because it houses several universities and research centers that require translations of scientific material from Spanish into English, but it also houses, for example, pharmaceutical companies that require translations from English into Spanish to ensure that the information on imported chemical products reaches the community appropriately. Bahía Blanca city (in the south of Buenos Aires province, Argentina), instead, seems to show that the number of translations from Spanish into English is higher than that of translations from English into Spanish in reply to its principal activities which are concentrated around Ingeniero White Port, universities, and a scientific and technological center dependent on the UNS and the National Research Council (CONICET). The latter two require - almost on a daily basis-widely varied texts properly written in English. All in all, although it is necessary to have the support of statistical indicators confirming whether scientific translations from Spanish into English are requested in higher percentage than from English into Spanish in South América, the current scenario in this vast territory is such that the scientific translator must be prepared to respond to both alternatives.

\section{Linguistic Tools for the Scientific Translator}

Taking all the above into account, the question that arises is: Which are the tools that can help the scientific translator work in a context of so many pressures? The tools are of different nature, mainly linguistic, technological, and sociocultural. Independently of whether one is thought as more important than the others, it is necessary to adopt a generalist approach. By the term 'generalist,' I mean an approach that thoroughly explores and pays attention to linguistic issues specific to scientific discourse and extralinguistic issues that are straightforwardly related to the daily routine of the scientific work. In the former case, apart from grammar and language, modern translation programs should include not only linguistic 
issues related to the 'South American labor market' needs (e.g., regulations regarding Spanish language varieties vs. standard or international Spanish; linguistic treatment for local terms, translation of vulgar names of local species, etc.) but also a praxis consisting of fully intensive and extensive reading of scientific discourse in Spanish and in English. This is because translation students are-in general—not familiarized with scientific texts written either in their own mother tongue or in English (Soler 2002).

In this respect, genre theory, which arose from ideas discussed in Plato's Republic and Aristotle's Poetics, becomes a key tool to train scientific translators. It deals with the human need to classify the world in such a way that entities with similar characteristics and the process of labeling them help to say something about them (Pawlicki 2017). Based on this original idea, genres are therefore convenient analytical labels which, from the point of view of discourse analysis, show that communicative events are framed following selection and organization patterns at different language levels. These events display a set of communicative purposes which are identified and mutually understood only by those who are members of a community (e.g., academic or professional) within which these events occur (Martin 1992), leaving out those who do not belong to this community. Scientific translation training programs should therefore include theory and practice work on all varieties of scientific genres (highly advanced scientific research and review papers, posters, case reports, $\mathrm{PhD}$ theses) both in English and in Spanish, comparative and contrastive analyses of authentic genre samples resulting to be incredibly useful didactic resources (Soler 2014).

Register analysis could perfectly work as a complementary tool to genre analysis in scientific translation teaching programs. Register, the context-specific variety of language, is the parameter that indicates the lexical and grammatical choices speakers and writers make depending on the situational context (Halliday 1994) which includes three aspects: field, tenor, and mode. Field refers to the subject matter that is discussed, tenor is the variable that indicates the relationship between the author and the audience, and mode is the means through which communication is achieved (writing, oral presentation, etc.). Raising scientific translation students' awareness of field, tenor, and mode is central to differentiate scientific discourse (highly- and semi-specialized) from popular scientific discourse and from didactic scientific discourse (or didactic discourse of science). To this end, text reformulation exercises designed with authentic scientific text samples as a strategy to adapt them to a 
variety of registers in English and Spanish are useful didactic tools because they stimulate critical thinking and, in turn, raise genre-register sensitivity.

An interesting correlation can be observed between genre/register and the languages into which texts should be translated in South América, as the need to translate into Spanish or English seems to depend mainly on the genre and discursive register of the source document. Thus, in the case of popular scientific discourse and/or scientific didactic discourse, the need for translations from English into Spanish is higher than for translations into English. In contrast, in the case of highly advanced scientific discourse, the need for translations into English in South América is exactly the opposite. The scientific translator must be therefore trained to respond to both alternatives in which genre and register of the texts to translate are very dissimilar.

The above leads to the consideration of another professional area in South América where the scientific translator is also greatly necessary: the courts of justice. In the latter, specifically in cases of professional malpractice legal proceeding a 'hybrid' translator is the solution. The term 'hybrid' is used in the sense that in this case the translator must be a certified translator with expertise in scientific translation. The need for such hybridity lies in that in the majority of professional malpractice proceedings the intervening parties include highly advanced scientific literature written in English as documentary evidence. In this respect, article 6 of Act No. 20.305 of 25 April 1973 ("Traductores Públicos" [Certified translators] $)^{1}$ states that "any document submitted in a foreign language to public, judicial, or administrative offices in the territory of the Republic of Argentina must be accompanied by the respective translation into the national language signed by a certified translator" (my translation). Interestingly, textual documentary evidence consisting of highly advanced scientific literature has not only a clear genre category but also a clear register type. In theory, the intervening certified translator who-as stated above-must have expertise in scientific translation is expected to be faithful to the genre and register of the source document. Still, a translation of this type (i.e., faithful to the genre and register of the source document) may not necessarily be useful to the lawyers and the judge in charge of the legal proceeding and may therefore hinder the progress of the legal process. The reason why this may occur is that highly advanced scientific literature is written to the community of scientists to which neither

\footnotetext{
${ }^{1}$ Available at https://www.argentina.gob.ar/normativa/nacional/ley-20305-194196/texto.
} 
lawyers nor judges belong. This is a typical genre-based and register-based problem that only a hybrid translator may solve by means of an audience-based adaptation of probatory documentation rather than a faithful translation of such source text. Therefore, only with a skill of such a singular intellectual complexity can the 'hybrid translator' successfully translate or - better say—adapt the source document addressed to scientists in a way that can be understood by non-scientists. Accuracy as well as prudence are therefore crucial ingredients to ensure that such a translation fulfills its purpose whose major impact will fall upon the final judgement of a judicial proceeding.

The above clearly shows the potential of genre and register as tools to go deep into scientific texts written in English and Spanish. In parallel, Systemic Functional Linguistics (SFL), an approach to linguistics that considers language as a social semiotic system, is also a very useful tool to analyze authentic scientific text samples belonging to different genres and registers. It develops a theoretical and methodological framework of analysis whose starting point is a description of language as a resource for constructing meaning (Halliday 1994). Within SFL, the language of science is conceived as a construction of meanings straightforwardly related to knowledge and its realizations in discourse, the latter being lexicogrammatical constructions that fulfill different forms of cognitive and semiotic practices that everyday language cannot perform. In this sense, the linguistic work of science is not only lexical but also grammatical (Vallejos Llobet 2000).

Based on the theoretical rationale of SFL, an attempt was made to see its operability to record applications to the teaching of translation and reading scientific discourse, particularly highly advanced scientific discourse (Soler 1999, 2002, 2003, 2005). The results collected from these studies allowed us to develop tools i) for the analysis and semantic classification of specific linguistic elements (e.g., adjectives and their textual behavior in different sections of research and review articles and $\mathrm{PhD}$ theses) (Soler 2002, 2003, 2018), and ii) for the analysis of scientific titles and their translations from Spanish into English and vice versa (Soler 2007a, 2009b). Both SFL and genre theory were useful to identify the following in research and review papers: disciplinary linguistic features, generic characteristics, and the criteria ruling the preference for specific linguistic elements, such as adjectives in different sections of scientific papers and title structural configurations straightforwardly related to the discipline and the scientific genre in which they are used (Soler 2003, 2005, 2007a, 2009b, 2011). Although further studies are necessary, mainly on larger databases than those used to 
date, the data collected are of considerable importance as they can guide the scientific translator to decode both adjectival behavior and title structuring appropriately in the source language and to subsequently encode them into equivalences in the target language. To this end, different practical decoding and encoding activities centered on text samples from different scientific genres and registers have been proposed to help translation students overcome the hardships proper of scientific translation (Soler 2014).

The preceding synopsis listing tools for the translator's work must also include the important work performed by Hans J. Vermeer and Katharina Reiss on skopos theory and text types, respectively (Reiss and Vermeer 2013). These two theorists moved away from the linguistic turn, according to which it is imperative to make sure the target text contains the exact meaning portrayed in the source text, to explore the relationships between a text and not only the audience but also the role of the target text in the target culture. Their contributions complement each other in that they introduce a shift in the translation paradigm from linguistically oriented concepts to a functionally and socioculturally oriented framework claiming that any translation is a goal-oriented action.

This shift is related to another important issue that needs major attention and which concerns the extralinguistic side of translation programs as the majority of scientific translators in South América - among whom I include myself - must have referred several times to the fact that the knowledge and skills gained at the university do not always fulfill the needs required in the workplace, forcing them to cope with problems in workplace communication that are unlikely to be learnt in translation courses at the university. Internships in research centers are mandatory in this case to serve as a bridge between classroom knowledge and real-world practice. As, for reasons of brevity, this issue cannot be further detailed herein, Soler's (2007b) reflections on the extralinguistic side that significantly influences the work of the scientific translator are suggested for reading.

\section{Concluding Remarks}

Genre theory as well as SFL-based theoretical-methodological framework are appropriate tools to deal with the problem of how to mean in science. SFL, in particular, analyzes how scientists represent the experiential world, how they interrelate with their peers and/or with their peer and non-peer audience, and how this representation of the world and 
this sender/receiver interrelationship are fused in a text to mean. Genre theory, on the other hand, guides the scientific translator to identify the different linguistic formats used by scientific texts to achieve specific objectives. Such identification is necessary so that the translator, who must be familiar with the linguistic and cultural codes of the source and target languages, can decode the source language of a scientific text accurately and appropriately and encode it in the target language.

Taking all the above into account, it is important to agree that the scientific translator is a trilingual expert (i.e., an expert displaying high competence in the source language, the target language, and the language of science). This professional trilingual expertise must be compatible with the dizzying speed of science work and is expected to be always successfully operative although the scientific translator is generally not an expert on the subject field, or at least not to the same extent as the author of the source text and the intended audience, particularly in the case of highly advanced scientific source documents. Faced with so many linguistic and extralinguistic pressures in South América, the scientific translator is a magician who greatly contributes to the dissemination of knowledge. In line with this, the reflections discussed in this paper are attempts to be a 'therapeutic' supportive intervention aiming at raising awareness of the pivotal role of the scientific translator in a vast Spanishspeaking territory to make knowledge available to everyone and to equip him/her with realistic linguistic and extralinguistic tools at the university during the training period and at research centers during the working period. 


\section{References}

Diéguez Morales, María Isabel, Rosa María Lazo Rodríguez, and Camilo Quezada Gaponov. 2014. "Estudio de mercado de la traducción en Argentina, Chile y España: perfil académico y profesional de los traductores." [Market study of translation in Argentina, Chile and Spain: Translator's academic and professional profile.] Onomázein, no. 30, 70-89. doi:10.7764/onomazein.30.6.

Halliday, Michael A. K. 1994. An Introduction to Functional Grammar. London: Edward Arnold.

Macshane, Frank. 1976. "La enseñanza de la traducción." [The teaching of translation.] Revista SUR. Problemas de la Traducción 338-339:68-77. Buenos Aires: Editorial Sur.

Martin, James R. 1992. English Text: System and Structure. Amsterdam: John Benjamins.

Orellana, Marina. 1986. La traducción del Inglés al Castellano: Guía para el Traductor [Translation from English into Spanish: A translator's guide]. Santiago de Chile: Editorial Universitaria.

Pawlicki, Kamil. 2017. "Genre Theory Applied: Genre and Form Terms in the National Library of Poland Catalogue." Paper presented at IFLA World Library and Information Congress: Libraries. Solidarity. Society, Wrocław, August 21.

Reiss, Katharina, and Hans J. Vermeer. 2013. Towards a General Theory of Translational Action: Skopos Theory Explained. Translated by Christiane Nord. English reviewed by Marina Dudenhöfer. Manchester: St. Jerome.

Soler, Viviana. 1999. "De la interpretación del científico a la interpretación del traductor." [From the scientist's interpretation to the translator's interpretation.] Speech delivered at Primeras Jornadas de Traducción Literaria y Científica: "La Traducción al final del milenio" [First Meeting on Literary and Scientific Translation: "Translation at the End of the Millennium"], Santa Rosa, La Pampa, Argentina, August 7.

2002. "Aportes de la perspectiva sistémico-funcional en la formación del traductor científico." [Contributions of the systemic functional perspective to the training of the scientific translator.] Tradução Et Comunicação. Revista Brasileira de Tradutores, 11:71-92.

2003. "Títulos y adjetivos en ciencia 'bajo la lupa': implicancias para su traducción." [Titles and adjectives under the 'magnifying glass': Implications for their translation.] Speech delivered at IV Congreso Latinoamericano de Traducción e Interpretación [4th Latin-American Congress of Translation and Interpretation], Buenos Aires, Argentina, May 1-4. 
2004. "English in the World of Science." Paper presented at 10th National Congress of Teachers and Students of English, Bahía Blanca, Argentina, July 9-10.

2005. "Lo que nos dicen los títulos científicos especializados." [What specialized scientific titles say.] Paper presented at III Coloquio Nacional de Investigadores en Estudios del Discurso [3rd National Colloquium of Researchers in Discourse Studies], Universidad Nacional del Sur, Bahía Blanca, Argentina, August 4-7.

2006a. "El lenguaje de la ciencia: Un desafío para el traductor." [The language of science: A challenge for the translator.] Speech delivered at III Jornadas de Plurilinguismo y VIII Jornadas de Intercambio Metodológico en la Enseñanza de las Lenguas [3rd Conference on Multilingualism and 8th Conference on Methodological Exchange in Language Teaching], Escuela Normal Superior de la Universidad Nacional del Sur, Bahía Blanca, Buenos Aires, Argentina, June 20.

2006b. "Compartiendo fragmentos de la revista Traduçao \& Comunicação sobre lo lingüístico y lo no-lingüístico como condición sine qua non en respuesta a los desafíos del traductor científico." [Sharing excerpts from the journal Traduçao \& Comunicação on linguistic and non-linguistic issues as a sine qua non condition in response to the challenges of the scientific translator.] Speech delivered at V Jornada de Actualización Profesional en Traducción e Interpretación "Traducir en la Argentina: Un desafío Permanente" [5th Professional Updating Meeting on Translation and Interpretation "To Translate in Argentina: A Permanent Challenge"], Universidad Nacional del Sur, Bahía Blanca, Buenos Aires, Argentina, October 28.

2007a. "Writing Titles in Science: An Exploratory Study." English for Specific Purposes 26 (1): 90-102. doi:10.1016/j.esp.2006.08.001.

2007b. "Simbiosis de lo lingüístico y lo no-lingüístico en la formación del traductor científico." [Symbiosis of linguistic and non-linguistic variables in the training of the scientific translator.] Tradução Et Comunicação. Revista Brasileira de Tradutores, 16:91-100.

2009a. "Anecdotario y reflexiones de un traductor en el sistema científico argentino." [Anecdotes and reflections of a translator in the Argentine scientific system.] Paper read in absentia at V Jornadas de la Escuela Superior de Idiomas [5th Conference of the Escuela Superior de Idiomas], Universidad Nacional del Comahue, General Roca, Argentina, October 17.

2009b. "Títulos científicos en lengua española: Estudio exploratorio.” [Scientific titles in the Spanish language: Exploratory study.] Lebende Sprachen 54 (2): 50-58. doi:10.1515/les.2009.017.

2011. "Comparative and Contrastive Observations on Scientific Titles Written in English and Spanish." English for Specific Purposes 30 (2): 124-137. doi:10.1016/j.esp.2010.09.002. 
. 2014. "Highly Advanced Scientific Titles in the Field of Reading Pedagogy." Encuentro. Revista de Investigación e Innovación en la Clase de Idiomas, no. 23, 142-151. https://ri.conicet.gov.ar/bitstream/handle/11336/4548/CONICET_Digital_Nro.5732_A.pdf? sequence $=2 \&$ is Allowed $=\mathrm{y}$.

—. 2018. "Estudio exploratorio de títulos de tesis doctorales redactados en lengua española." [Exploratory study of titles of $\mathrm{PhD}$ theses written in Spanish.] Lebende Sprachen 63 (2): 374-392. doi:10.1515/les-2018-0022.

Vallejos Llobet, Patricia, ed. 2000. Prácticas discursivas en la producción del conocimiento científico [Discursive practices in knowledge production]. Bahía Blanca: Editorial Universidad Nacional del Sur. 